EISSN: 2706 -7947 ISSN: 2077- 4613

DOI: $10.36632 / \mathrm{mejas} / 2021.11 .3 .50$

Journal homepage: www.curresweb.com

Pages: 625-636

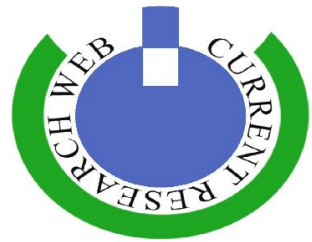

\title{
Effect of Packaging and Cold Storage on the Quality of Sweet Basil Herb
}

\author{
T.F.A. El-Moghazy
}

Medicinal and Aromatic Plants Res. Dept., Hort. Res. Inst., Agric. Res. Center, Giza, Egypt

Received: 02 June 2021 Accepted: 10 July $2021 \quad$ Published: 20 July 2021

\begin{abstract}
Storage and packaging are among factors affecting the quality properties of fresh herbs. Sweet basil (Ocimum basilicum L.) is an important herb used for fresh and dry consumption and as a source of volatile oil. The aim of this study was to evaluate fresh sweet basil herb in response to packaging and cold storage treatments. Experiments were carried out at Sabahia Horticulture Research Station, Alexandria Governorate, Egypt. Samples (100g) were packed at seven different packages; unpacked (control), 3 punnets polyethylene (PE); Non-perforated polyethylene packaging (NPPEP), Lowperforated polyethylene packaging (LPPEP) and Medium-perforated polyethylene packaging (MPPEP), and 3 punnets polypropylene (PP); Non-perforated polypropylene packaging (NPPPP), Lowperforated polypropylene packaging (LPPPP) and Medium-perforated polypropylene packaging (MPPPP). The fresh sweet basil herb was stored at $7^{\circ} \mathrm{C}$ during storage periods; $0,5,10$ and 15 days in the two seasons. Lost weight, decay, dry matter, chlorophyll content, volatile oil and its main constituents were investigated. Results showed that lost weight and decay, increased with increasing the storage period. Dry matter, chlorophyll and volatile oil decreased with increasing storage period. Active components increased at end of storage period. Storage packages (PE and PP) showed significant differences in lost weight, decay, dry matter, chlorophyll, volatile oil and active compounds during storage. It may be concluded that PP packages were better than PE packages in keeping fresh basil especially NPPPP and, LPPPP compared to other packages and control.
\end{abstract}

Keywords: Sweet basil herb, (Ocimum basilicum, L.), packaging, cold storage, volatile oils

\section{Introduction}

Sweet basil (Ocimum basilicum L.) belongs to family Lamiaceae. The cultivated area is estimated at about 13106 feddan in old and new lands (BAS, 2018/2019), Egypt. Sweet basil contains volatile oil; the main constituents are linalool, cineole, eugenol, isocaryophyllene, methyl cinnamate, and $\alpha-$ cubebene (Ismail, 2006). Several investigators found that the major compounds are linalool, 1, 8, cineol, eugenol, methyl cinnamate, camphor, methyl eugenol, methyl chavicol, $\beta$-elemene, $\beta$-ocimene, camphene, carvacrol, $\alpha$-bergamotene, $\alpha$-cadinol and geranial (Poonkodi, 2016). Leaves of sweet basil used in folk medicine as a tonic and vermifuge, and basil tea taken hot is good for treating nausea, flatulence and dysentery (Baytop, 1984), its volatile oil has been found to be beneficial for the alleviation of colds, rhinitis, spasm, mental fatigue, and as a first aid treatment for wasp stings and snakebites. Basil volatile oil was reported to have antimicrobial as well as antioxidant (Hussain et al., 2008 and Karagözlü et al., 2011). Also antifungal (Hossain et al., 2014a) and insecticidal (Popovic et al., 2006 and Hossain et al., 2014b). Properties 1, 8-cineole, linalool, and camphor, are known to be biologically active (Morris et al., 1979) as well as food industry and cosmetics (Avetisyan, et al., 2017).

After harvesting and sorting, medicinal and aromatic plants have three distinct destinations: sale of the fresh plants, extraction of their active components, or preservation by drying (Silva and Casali, 2000). Although freshly herbs are superior in flavor to dried herbs, their widespread commercialisation has been finite due to high perishability and a relatively short shelf-life (Cantwell and Reid, 1993). The Post-harvest treatments from packaging materials i.e. polyethylene (PE), polypropylene (PP) or carton as well as storage period and conditions have an effect on the quality from lost weight, decay,

Corresponding Author: T.F.A. El-Moghazy, Medicinal and Aromatic Plants Res. Dept., Hort. Res. Inst., Agric. Res. Center, Giza, Egypt 
chlorophyll content, volatile oil and its main constituents. Regarding the packaging materials, Sharma, et al.,(2018) found that low-density PE bags (LDPE) packaging and $5^{\circ} \mathrm{C}$ storage temperature maintained the quality of basil leaves for longer period probably by lowering the oxidative stress to larger extent due to enhanced activities of antioxidative enzymes and thus can be used to extend the shelf life of basil leaves. Also storage of sweet basil in perforated packaging, at $4^{\circ} \mathrm{C}$ provided maximum chlorophyll and vitamin $\mathrm{C}$ retained and minimum loss weight (Tay and Teo, 2019). Basil stored in PE bags lost less weight resulting in extended storage life compared to non-packed branches, packing basil in nonperforated PE bags resulted in decay after six days, perforated PE bags with 16 holes $\left(12.56 \mathrm{~cm}^{2} / \mathrm{bag}\right)$ provided the best condition in maintaining the quality of basil for 9 days (Jirapong et al., 2010). Rashed and Younis (2010), packed oregano in polypropylene (PP) was recorded the lowest total weight loss and decay $\%$ during storage. The most appropriate packaging material for extending shelf life of celery stalks were poly olefin (co-extruded) PE and PP with an antifogging additive (AF) (Rizzo, and Muratore, 2009).

Regarding the storage period, Abdel-Kader, et al., (2009) found that increasing storage period resulted increasing of the fresh lost weight and decreasing the total chlorophyll content of Rosemary. According to (Barbosa et al., 2016 and Tay and Teo, 2019) there are two phases during chlorophyll degradation of the plants during storage; in the first phase, as the mass and the water level decreased in the leaves the pigments became more concentrated, in the following, slight yellowing or loss of green color indicated the decreased in quality which observed in the medical plant as time passed. Basil plants synthesize and store essential oil (EO) in superficial peltate glands and trichomes (Gang et al., 2001). And also Rashed, and Younis (2010) the oil\% decreased by increasing storage period. Fresh basil presented a linear decrease in the oil \% along the storage period (Silva et al., 2005); the two major components of the EO were eugenol and linalool, the eugenol and linalool relative content increased during storage, the eugenol content increased sharper than linalool, and both presented the highest content at the end of storage period. On the other hand storage temperature, sensibility to chilling temperature has been observed higher in lemon basil and holy basil than in sweet basil in which the leaves darkening occurred within $24 \mathrm{~h}$ under cold storage at $4^{\circ} \mathrm{C}$ (Wongsheree et al., 2009). The expected shelf life for most herbs is up to three weeks at $32^{\circ} \mathrm{F}\left(0^{\circ} \mathrm{C}\right)$, but because basil is a component of many mixed herbs an intermediate temperature of 41 to $50{ }^{\circ} \mathrm{F}\left(5\right.$ to $10^{\circ} \mathrm{C}$ ) is required, this compromise temperature results in lower risk of chilling injury for basil (Watkins and Nock, 2012).

The objective of this work was to evaluate the permeability some types of packing containers from PE or PP and to study their impact on the quality and shelf life of fresh sweet basil (Ocimum basilicum, L.) under cold storage.

\section{Materials and Methods}

\subsection{Plant material and experimental design:}

This study was carried out at Sabahia Horticulture Research Station, Alexandria Governorate, Egypt. Sweet basil (Ocimum basilicum L.) grown in a private farm located in Mahmoudia, Beheira Governorate was the material of this study. Plant samples were cut on June $30^{\text {th }}$ in 2019 and 2020 seasons at $10 \mathrm{~cm}$ above soil surface without bruising and after recutting the stem ends to $20-25 \mathrm{~cm}$ in length. Samples (about $100 \mathrm{~g}$ ) were packed at seven different packaging (punnets) cases at $20 \times 15 \times 8$ $\mathrm{cm}$. The packaging treatments were:

1- Unpacked (control).

2- Non-perforated polyethylene packaging (NPPEP).

3- Low-perforated polyethylene packaging (LPPEP), 6 holes with diameter of $1 \mathrm{~cm}$ per each.

4- Medium-perforated polyethylene packaging (MPPEP), 12 holes with diameter of $1 \mathrm{~cm}$ per each.

5- Non-perforated polypropylene packaging (NPPPP).

6- Low- perforated polypropylene packaging (LPPPP), 6 holes with diameter of $1 \mathrm{~cm}$ per each.

7- Medium-perforated polypropylene packaging (MPPPP), 12 holes with diameter of $1 \mathrm{~cm}$ per each.

The fresh herb was stored at $7{ }^{\circ} \mathrm{C}$ during storage periods i.e. $0,5,10,15$, days in both seasons. The complete randomized design was used in the experiments ( 7 treatments) after all storage periods (4) with three replicates. Every replicate (9) samples. 


\subsection{Recorded data}

\section{Lost weight (\%)}

It equals the amount of water loss through evaporation and transpiration plus the amount of dry matter lost by respiration. It was determined by weighting the fresh herb during storage periods. Their weight loss was calculated as follows:

$$
\text { Lost weight }(\%)=\frac{\text { Initial weight- herb weight at exstorage date }}{\text { Initial weight }} \times 100
$$

\section{Decay (\%)}

The percentage of disordered herb included all of the spoiled herbs resulted from rots, the leaf darkening, abscission of leaves, fungus, bacterial and pathogens were assessed and the defects were calculated as follows:

$$
\text { Decay } \%=\frac{\text { Weight of decay }}{\text { Initial weight }} \times 100
$$

\section{Dry matter (\%)}

$$
\text { Dry matter } \%=\frac{\text { Dry Weight }}{\text { Fresh weight }} \times 100
$$

\section{Chlorophyll}

Chlorophyll contents (SPAD, values) were performed using the SPAD-502 meter (Minolta Co. LTD, Japan). The device measures transition of red light at $650 \mathrm{~nm}$, at which chlorophyll absorbs light, as well as transmission of infrared light at $940 \mathrm{~nm}$, at which no absorption happens (Hoel and Solhaug, 1998).

\section{Volatile oil (\%)}

Volatile oil percentage of the fresh herb $(100 \mathrm{gm})$ was utilized to a $3 \mathrm{~h}$ water-distillation using a Neo Clevenger apparatus, volatile oil ratio was calculated as a relative percentage $(\mathrm{v} / \mathrm{w})$ according to British Pharmacopoeia., (1963). Oils were dried by anhydrous sodium sulfate and stored in dark vials at $4^{\circ} \mathrm{C}$ for analysis.

\section{Chemical composition of volatile oil}

The Gas Chromatograph (GC) analysis of volatile oil of each treatment after 15 days (the end of storage) as comparing with the control after 5 days using DS 6200 GC with BPX5 capillary column and a flame ionization detector under the following operating conditions: sample size of $1 \mu 1$ and temperature increasing rate of $10^{\circ} \mathrm{C} / \mathrm{min}$ (from $70^{\circ} \mathrm{C}$ to $200^{\circ} \mathrm{C}$ ). The carrier gases were nitrogen, hydrogen, and air with flow rate of 30,30 and $300 \mathrm{~mL} / \mathrm{min}$, respectively. Major compounds of the volatile oils were identified by matching their retention times with those of the authentic samples injected under the same conditions. The percentage of volatile components were obtained by calculating the area under the peak appeared for each compound.

\subsection{Statistical Analysis}

The obtained data were statistically analyzed using analysis of variance (ANOVA) complete randomized design. The LSD was calculated to estimate the significant differences $(p<0.05)$ using a statistical software (Costat, version 6.303, 2005) according to Gomez \& Gomez (1984).

\section{Results and Discussion}

\subsection{Lost weight}

Data presented in Table (1), showed the effect of packing and cold storage on lost weight of fresh herb during both seasons. Unpackaged herb (control) recorded the highest significant lost weight. It was higher than $35 \%$ and $29.83 \%$ which the visual value of this plants become unsuitable after 5 days in the 
two seasons consecutively. This result is consistent with those obtained by Rashed and Younis, (2010) on fresh Origanum Syriacum, L. herb during storage, lost weight is a physiological event in fresh herbs that can be limited by controlling storage temperature and humidity, but also by using appropriate packaging. In this work, lost weight in all polypropylene (PP) packages was lower than polyethylene (PE) packages, during storage periods in the two seasons. The NPPPP was better than the NPPEP as well as the LPPPP kept lost weight at a lower level than LPPEP (Fig. 1). This results are in line with Rashed, and Younis 2010, Packed oregano in PP was recorded the lowest total weight loss during storage. The results showed that the top three packages that reduced weight loss for fresh basil herb during storage were NPPPP, NPPEP and LPPPP compared to the other packages. Tay and Teo 2019, Storage of sweet basil in perforated packaging, at $4^{\circ} \mathrm{C}$ provided minimum lost weight. Basil stored in $\mathrm{PE}$ bags lost less weight resulting in extended storage life compared to non-packed branches (Jirapong et al., 2010).

Regarding the impact of storage period, results obviously showed that lost weight were increased by extending the storage period of the first and second seasons Fig.2. Our results were similar to those reported by other researchers (Rashed and Younis, 2010) who observed increase the lost weight of fresh Origanum Syriacum, L. herb during storage. Also increasing the storage period resulted in increasing of weight loss percentage, as may be attribute to excess in water loss by long storage (Abdel-Kader, et al., 2009). Similar results were obtained by Gomez et al., (1999) on coriander.

On the other hand the interaction influence between treatments and storage period (Table, 1), the obtained results indicated that the interactions registered the lowest values of lost weight after 5, 10 and 15 days in NPPPP, NPPEP and LPPPP of both seasons.

Table 1: Effect of packaging and cold storage on lost weight (\%) of fresh Basil (Ocimum basilicum, L.) during 2019 and 2020 seasons.

\begin{tabular}{|c|c|c|c|c|c|c|c|c|c|c|}
\hline \multirow{3}{*}{ Treatments } & \multicolumn{5}{|c|}{$1^{\text {st }}$ Season 2019} & \multicolumn{5}{|c|}{$2^{\text {nd }}$ Season 2020} \\
\hline & \multicolumn{5}{|c|}{ Storage Periods (Days) } & \multicolumn{5}{|c|}{ Storage Periods (Days) } \\
\hline & $\mathbf{0}$ & 5 & 10 & 15 & Mean & $\mathbf{0}$ & 5 & 10 & 15 & Mean \\
\hline Control & 0.00 & 35.00 & $62.66^{\mathrm{EX}}$ & $74.33^{\mathrm{EX}}$ & 43.00 & 0.00 & 29.83 & $60.51^{\mathrm{EX}}$ & $72.66^{\mathrm{EX}}$ & 40.75 \\
\hline NPPEP & 0.00 & 0.00 & 1.16 & 1.70 & 0.71 & 0.00 & 0.00 & 1.50 & 1.63 & 0.78 \\
\hline LPPEP & 0.00 & 1.65 & 4.66 & 7.00 & 3.32 & 0.00 & 1.33 & 3.50 & 7.15 & 2.99 \\
\hline МРPЕР & 0.00 & 4.00 & 6.66 & 11.00 & 5.41 & 0.00 & 3.36 & 5.69 & 9.48 & 4.63 \\
\hline NPPPP & 0.00 & 0.00 & 0.16 & 0.50 & 0.16 & 0.00 & 0.00 & 0.44 & 0.56 & 0.25 \\
\hline LPPPP & 0.00 & 0.00 & 1.33 & 4.00 & 1.33 & 0.00 & 0.83 & 1.36 & 3.30 & 1.37 \\
\hline МРРРР & 0.00 & 2.00 & 5.00 & 7.00 & 3.50 & 0.00 & 1.48 & 4.48 & 8.96 & 3.73 \\
\hline \multirow[t]{2}{*}{ Mean } & 0.00 & 06.09 & 11.66 & 15.07 & & 0.00 & 05.26 & 11.06 & 14.82 & \\
\hline & $\mathrm{T}$ & & & & $=0.41$ & $\mathrm{~T}$ & & & & $=0.47$ \\
\hline \multirow[t]{2}{*}{ LSD at 0.05} & $\mathrm{D}$ & & & & $=0.31$ & $\mathrm{D}$ & & & & $=0.35$ \\
\hline & $\mathrm{T} \times \mathrm{D}$ & & & & $=0.82$ & $\mathrm{~T} \times \mathrm{D}$ & & & & $=0.94$ \\
\hline
\end{tabular}

T: treatments, D: storage time, $\mathrm{T} \times \mathrm{D}$ : interaction, EX, Exstorage .

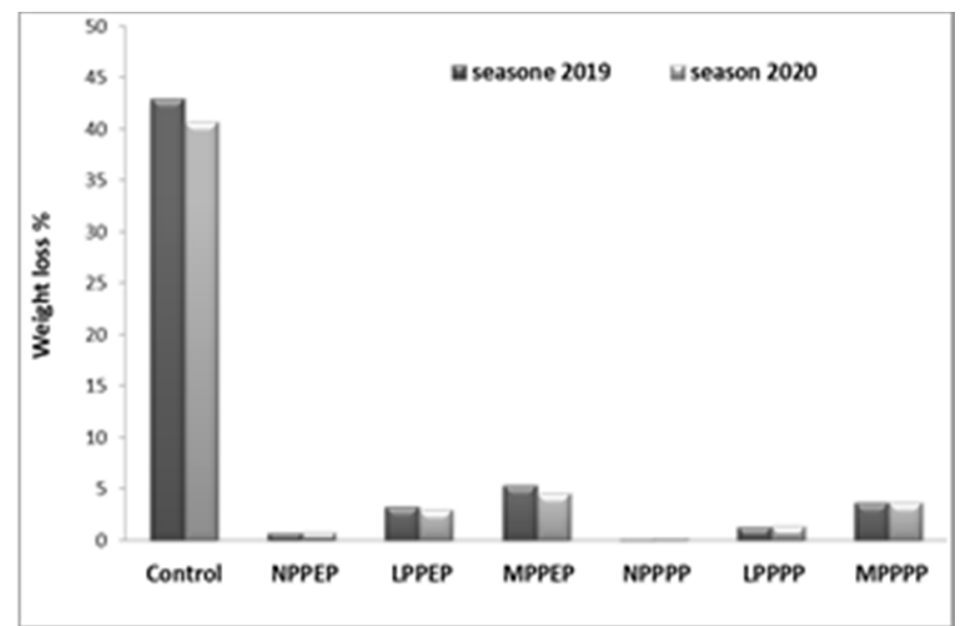

Fig. 1: Impact of packaging on weight loss \%. 


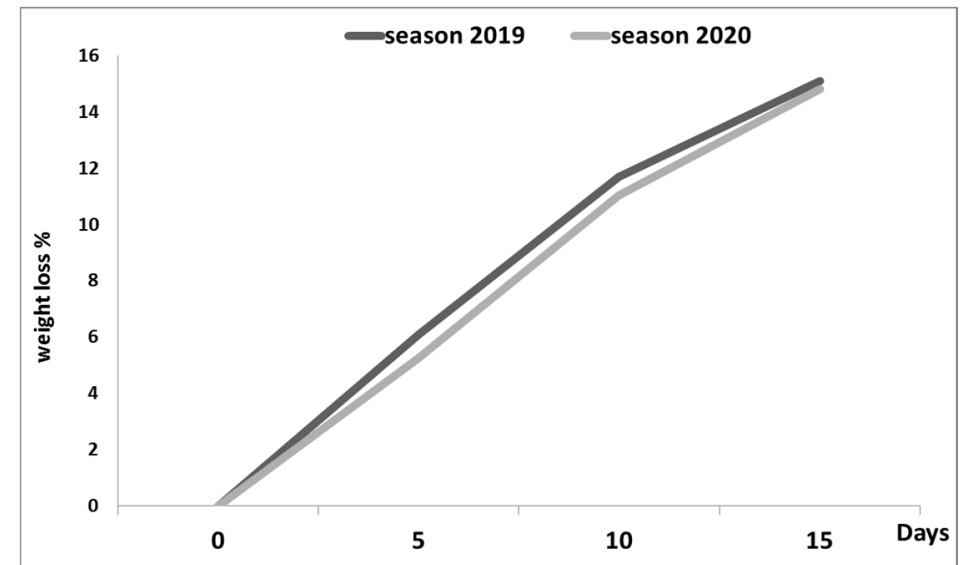

Fig. 2: Impact of storage period on weight loss $\%$.

\subsection{Decay}

Data in Table (2), showed that effect of packing and cold storage on decay of fresh Basil herb. Obtained results revealed that unpackaged (control) scored the highest significant decay over than the other packages, while LPPPP, NPPPP, LPPEP and NPPEP showed low deterioration during storage, respectively, (Fig. 3).

Regarding the impact of storage period, results indicated that decay \% was increased by extending the storage period in both seasons Fig. (4). and the differences among all tested storage periods were significant comparing with the initial date in the two seasons of study.

Table 2: Effect of packaging and cold storage on decay (\%) of fresh Basil (Ocimum basilicum, L.) during 2019 and 2020 seasons.

\begin{tabular}{|c|c|c|c|c|c|c|c|c|c|c|}
\hline \multirow{3}{*}{ Treatments } & \multicolumn{5}{|c|}{$1^{\text {st }}$ Season 2019} & \multicolumn{5}{|c|}{$2^{\text {nd }}$ Season 2020} \\
\hline & \multicolumn{5}{|c|}{ Storage Periods (Days) } & \multicolumn{5}{|c|}{ Storage Periods (Days) } \\
\hline & $\mathbf{0}$ & 5 & 10 & 15 & Mean & $\mathbf{0}$ & 5 & 10 & 15 & Mean \\
\hline Control & 0.00 & 11.33 & $100.00^{\mathrm{EX}}$ & $100.00^{\mathrm{EX}}$ & 52.83 & 0.00 & 11.83 & $100.00^{\mathrm{EX}}$ & $100.00^{\mathrm{EX}}$ & 52.95 \\
\hline NPPEP & 0.00 & 0.00 & 8.35 & 24.33 & 8.17 & 0.00 & 0.00 & 8.53 & 23.83 & 8.09 \\
\hline LPPEP & 0.00 & 0.00 & 7.01 & 21.00 & 7.00 & 0.00 & 0.00 & 7.83 & 21.50 & 7.33 \\
\hline МРPEP & 0.00 & 3.33 & 12.00 & 26.00 & 10.33 & 0.00 & 2.83 & 12.00 & 25.66 & 10.12 \\
\hline NPPPP & 0.00 & 0.00 & 6.16 & 19.66 & 6.45 & 0.00 & 0.00 & 5.5 & 18.83 & 6.08 \\
\hline LPPPP & 0.00 & 0.00 & 5.00 & 17.66 & 5.66 & 0.00 & 0.00 & 4.50 & 16.50 & 5.25 \\
\hline МPPPP & 0.00 & 1.66 & 9.00 & 24.34 & 8.75 & 0.00 & 2.00 & 9.16 & 23.00 & 8.54 \\
\hline Mean & 0.00 & 2.33 & 21.07 & 33.28 & & 0.00 & 2.38 & 21.07 & 32.76 & \\
\hline LSD at 0.05 & $\begin{array}{l}\mathrm{T} \\
\mathrm{D} \\
\mathrm{T} \times \mathrm{D}\end{array}$ & & & & $\begin{array}{l}=0.48 \\
=0.36 \\
=0.96\end{array}$ & $\begin{array}{l}\mathrm{T} \\
\mathrm{D} \\
\mathrm{T} \times \mathrm{D}\end{array}$ & & & & $\begin{array}{l}=0.49 \\
=0.37 \\
=0.99\end{array}$ \\
\hline
\end{tabular}

$\mathrm{T}$, treatments, $\mathrm{D}$, storage time, $\mathrm{T} \times \mathrm{D}$, interaction, $\mathrm{EX}$, Exstorage. 


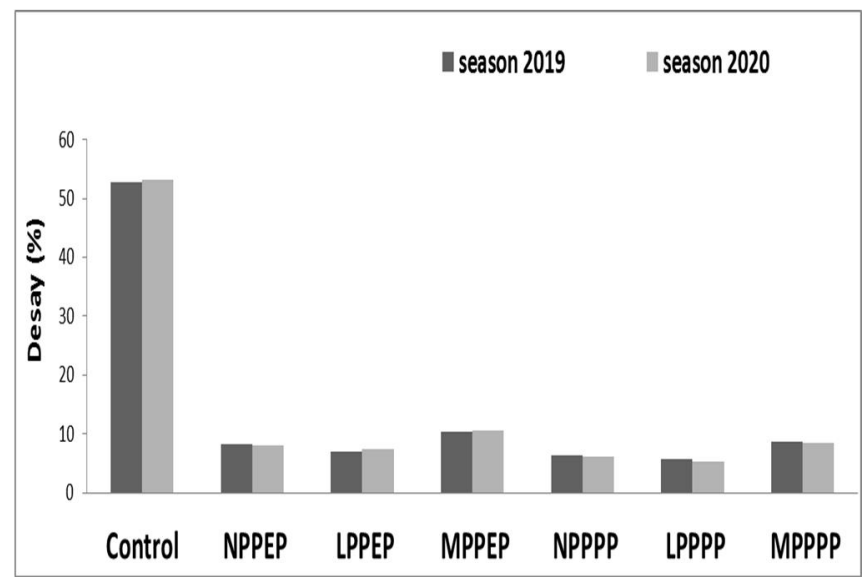

Fig. 3: Impact of packaging treatments on decay.

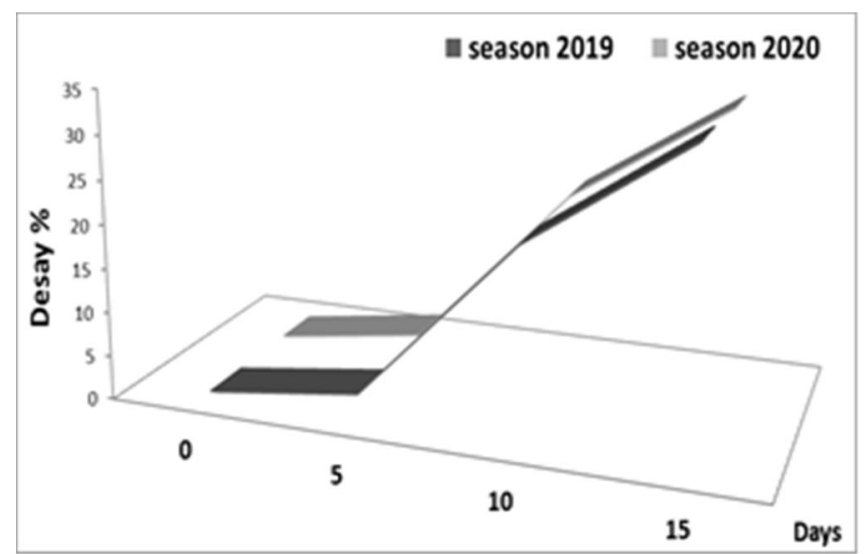

Fig. 4: Impact of storage period on decay.

On the other hand the interaction influence between treatments and storage period, showed that unpackaged (control) recorded the highest level of decay than the other packages after 5 days, while NPPPP, LPPPP, NPPEP and LPPEP treatments did not show any deterioration in the same period of storage. Also the best package was LPPPP to keep the Basil at an acceptable level throughout the storage period. These results may be due storage temperature and packing are most important factors affecting the shelf life of fresh herb. These results are in line with Jirapong et al., 2010, packing basil in nonperforated-PE bags resulted in decay after six days, perforated PE bags with 16 holes $(12.56 \mathrm{~cm} 2 / \mathrm{bag})$ provided the best condition in maintaining the quality of basil for 9 days. Furthermore, Rashed, and Younis 2010, Packed oregano in PP was recorded the lowest total decay \% during storage. The most appropriate packaging material for extending shelf life of celery stalks were poly olefin (co-extruded) PE and PP with an antifogging additive (AF) (Rizzo, and Muratore, 2009).

\subsection{Dry mater}

Having considered the Table (3), it can be easily inferred that effect of packing and cold storage on dry mater of fresh herb during 2019 and 2020 seasons. The PP, NPPPP and LPPPP gave higher dry matter, than PE, NPPEP, LPPEP and unpacked (control) during storage (Fig. 5).

With regard to the effect of storage period, the dry matter decreased during storage period in the two seasons (Fig. 6), the differences were big enough to be significant compared with zero time. These results may be due to excess in weight loss \% by long storage period as confirmed by (Rashed, 2007).This result was in agreement with those reported by Rashed and Younis, 2010 on fresh Origanum Syriacum, L. herb during storage.

The interaction between treatments and storage period, showed that unpackaged (control) recorded the lower level of dry matter than other packages after 5, 10, 15 days in both seasons. 
Table 3: Effect of packaging and cold storage on dry mater (\%) of fresh Basil (Ocimum basilicum, L.) during 2019 and 2020 seasons.

\begin{tabular}{|c|c|c|c|c|c|c|c|c|c|c|}
\hline \multirow{3}{*}{ Treatments } & \multicolumn{5}{|c|}{$1^{\text {st }}$ Season 2019} & \multicolumn{5}{|c|}{$2^{\text {nd }}$ Season 2020} \\
\hline & \multicolumn{5}{|c|}{ Storage Periods (Days) } & \multicolumn{5}{|c|}{ Storage Periods (Days) } \\
\hline & $\mathbf{0}$ & 5 & 10 & 15 & Mean & $\mathbf{0}$ & 5 & 10 & 15 & Mean \\
\hline Control & 25.83 & 23.00 & 19.50 & 18.00 & 21.58 & 26.20 & 24.00 & 20.20 & 18.33 & 22.18 \\
\hline NPPEP & 25.83 & 24.66 & 24.33 & 23.00 & 24.45 & 26.20 & 25.22 & 24.94 & 24.46 & 25.20 \\
\hline LPPEP & 25.83 & 24.16 & 23.00 & 21.66 & 23.66 & 26.20 & 25.10 & 24.76 & 24.36 & 25.10 \\
\hline МРPEP & 25.83 & 23.83 & 22.33 & 20.00 & 22.99 & 26.20 & 24.94 & 24.50 & 23.76 & 24.85 \\
\hline NPPPP & 25.83 & 25.00 & 25.66 & 26.00 & 25.62 & 26.20 & 25.73 & 25.60 & 25.23 & 25.69 \\
\hline LPPPP & 25.83 & 25.16 & 25.01 & 25.00 & 25.25 & 26.20 & 25.45 & 25.23 & 24.57 & 25.36 \\
\hline МРPРP & 25.83 & 23.83 & 22.00 & 19.66 & 22.83 & 26.20 & 25.13 & 25.10 & 24.07 & 25.12 \\
\hline Mean & 25.83 & 24.23 & 23.11 & 21.90 & & 26.20 & 25.08 & 24.33 & 23.54 & \\
\hline & $\mathrm{T}$ & & & & $=0.57$ & $\mathrm{~T}$ & & & & $=0.56$ \\
\hline LSD at 0.05 & $\mathrm{D}$ & & & & $=0.43$ & $\mathrm{D}$ & & & & $=0.42$ \\
\hline & $\mathrm{T} \times \mathrm{D}$ & & & & $=1.14$ & $\mathrm{~T} \times \mathrm{D}$ & & & & $=1.11$ \\
\hline
\end{tabular}

$\mathrm{T}$, treatments, $\mathrm{D}$, storage time, $\mathrm{T} \times \mathrm{D}$, interaction.

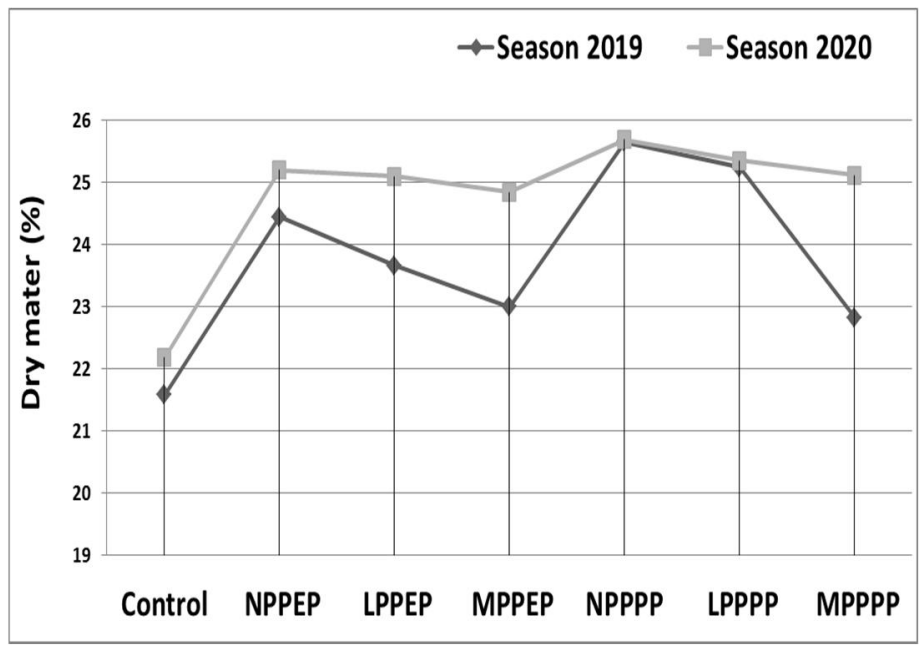

Fig. 5: Impact of packaging on dry mater \%.

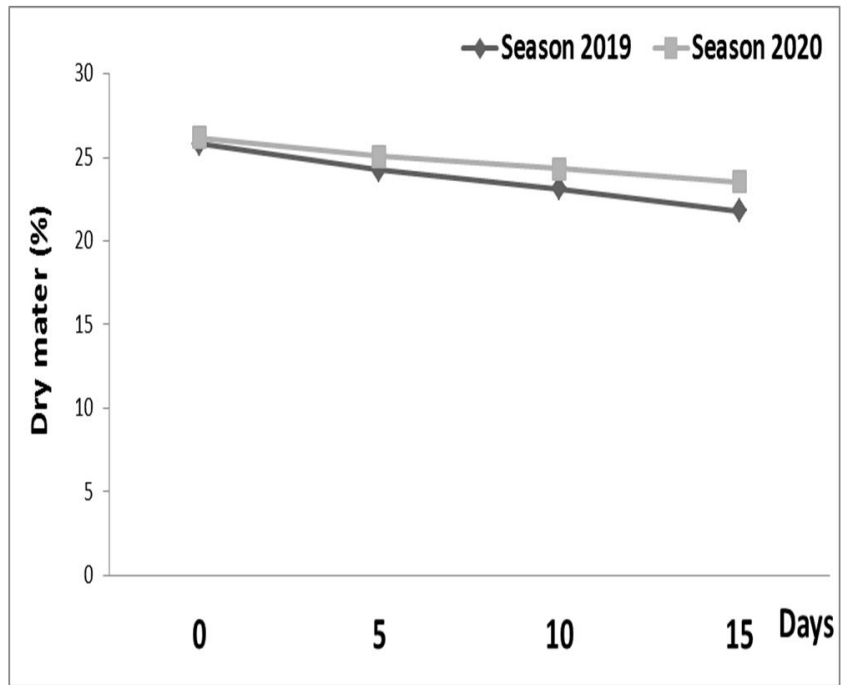

Fig. 6: Impact of storage period on dry mater \%.

\subsection{Chlorophyll}

From the data described in Table (4) and Fig.(7), effect of packing and cold storage on chlorophyll content of fresh Basil (Ocimum basilicum, L.) in 2019 and 2020 seasons. It is clear that, the unpackaged (control), MPPEP and MPPPP recorded the highest level significant of chlorophyll content 
after storage compared with other packages. This may be due to excess lost water in fresh herb and it increases the concentration of pigments. Also PP packages (NPPPP - LPPPP) and PE packages (NPPEP - LPPEP) saved an acceptable level of chlorophyll than other packages after 15 days of storage. These results are in line with those stated by Rashed and Younis, (2010) on fresh Origanum Syriacum, L. herb during storage. The total chlorophyll content was affected by using different packaging materials under the same cooling temperature (Loaiza and Cantwell, 1997 and Lange, 2000).

Table 4: Effect of packaging and cold storage on chlorophyll content of fresh Basil (Ocimum basilicum, L.) during 2019 and 2020 seasons.

\begin{tabular}{|c|c|c|c|c|c|c|c|c|c|c|}
\hline \multirow{3}{*}{ Treatments } & \multicolumn{5}{|c|}{$1^{\text {st }}$ Season 2019} & \multicolumn{5}{|c|}{$2^{\text {nd }}$ Season 2020} \\
\hline & \multicolumn{5}{|c|}{ Storage Periods (Days) } & \multicolumn{5}{|c|}{ Storage Periods (Days) } \\
\hline & $\mathbf{0}$ & 5 & 10 & 15 & Mean & $\mathbf{0}$ & 5 & 10 & 15 & Mean \\
\hline Control & 35.38 & 41.80 & 57.50 & 66.81 & 50.37 & 33.56 & 43.60 & 55.91 & 66.59 & 49.91 \\
\hline NPPEP & 35.38 & 34.80 & 35.76 & 36.14 & 35.52 & 33.56 & 33.32 & 35.41 & 37.60 & 34.97 \\
\hline LPPEP & 35.38 & 34.72 & 36.26 & 37.00 & 35.84 & 33.56 & 33.50 & 36.02 & 37.66 & 35.18 \\
\hline МРPEP & 35.38 & 39.17 & 41.05 & 45.96 & 40.39 & 33.56 & 38.90 & 40.95 & 44.90 & 39.58 \\
\hline NPPPP & 35.38 & 34.46 & 35.68 & 36.96 & 35.62 & 33.56 & 33.08 & 36.35 & 37.43 & 35.10 \\
\hline LPPPP & 35.38 & 34.65 & 36.74 & 37.08 & 35.96 & 33.56 & 33.15 & 36.64 & 37.50 & 35.21 \\
\hline МPPPP & 35.38 & 38.85 & 39.83 & 42.66 & 39.18 & 33.56 & 35.33 & 40.13 & 43.56 & 38.14 \\
\hline Mean & 35.38 & 36.92 & 40.40 & 43.23 & & 33.56 & 35.84 & 40.20 & 43.60 & \\
\hline \multirow{3}{*}{ LSD at 0.05} & $\mathrm{~T}$ & & & & $=0.92$ & $\mathrm{~T}$ & & & & $=0.86$ \\
\hline & $\mathrm{D}$ & & & & $=0.69$ & $\mathrm{D}$ & & & & $=0.65$ \\
\hline & $\mathrm{T} \times \mathrm{D}$ & & & & $=1.83$ & $\mathrm{~T} \times \mathrm{D}$ & & & & $=1.72$ \\
\hline
\end{tabular}

$\mathrm{T}$, treatments, $\mathrm{D}$, storage time, $\mathrm{T} \times \mathrm{D}$, interaction.

The interaction influence, showed that unpackaged (control) recorded the highest Chlorophyll content than the other packages after 5, 10, 15 days compared to other treatments Fig. (7). According to (Barbosa et al., 2016 and Tay and Teo, 2019) there are two phases during chlorophyll degradation of the plants; in the first phase, as the mass and the water level decreased in the leaves the pigments became more concentrated, in the following, slight yellowing or loss of green color indicated the decreased in quality which observed in the medical plant as time passed.

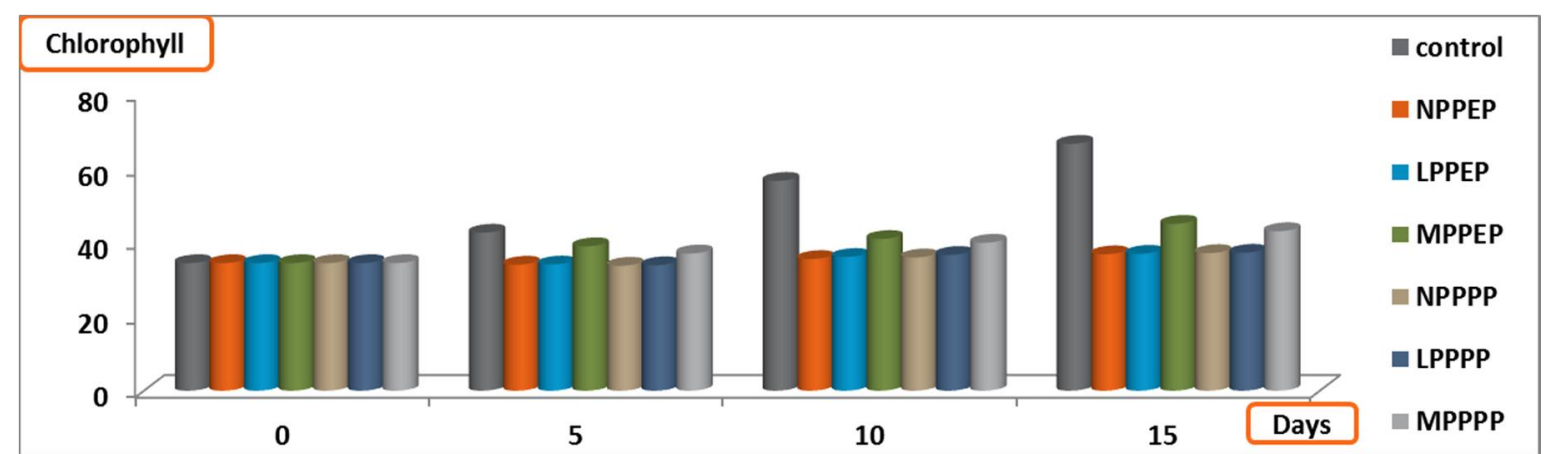

Fig. 7: Impact of interaction on Chlorophyll of fresh Basil (Ocimum basilicum, L.) in 2019 /2020 seasons.

\subsection{Volatile oil}

Effect of packing and cold storage on volatile oil (\%) of fresh herb during 2019 /2020 seasons, the presented data in Table (5) and Fig. (8), showed that all packages were better in keep the volatile oil (\%) compared to the control, also PP packaging was better than PE. The NPPPP and LPPPP scored highest volatile oil than NPPEP and LPPEP in the both seasons (Fig. 8).

Regarding the impact of storage period, results obviously showed that volatile oil decreased by increasing storage period after 5, 10,15 days (Fig. 9). These results are in line with Rashed and Younis 2010, on oregano. Basil plants synthesize and store essential oil (EO) in superficial peltate glands and trichomes (Gang et al., 2001). Fresh basil presented a linear decrease in the oil content along the storage period (Silva et al., 2005). This may be due to the effect of the higher respiration rates on product 
temperature, decomposition of organic matter, transpiration losses, reduction in external quality traits and decline inactive constituents (Bottcher, et al., 2001).

On the other hand, the interaction influence between treatments $\mathrm{x}$ storage period, non-significant in this study on volatile oil \%.

Table 5: Effect of packaging and cold storage on volatile oil (\%) of fresh Basil (Ocimum basilicum, L.) during 2019 and 2020 seasons.

\begin{tabular}{|c|c|c|c|c|c|c|c|c|c|c|}
\hline \multirow{3}{*}{ Treatments } & \multicolumn{5}{|c|}{$1^{\text {st }}$ Season } & \multicolumn{5}{|c|}{$2^{\text {nd }}$ Season } \\
\hline & \multicolumn{5}{|c|}{ Storage Periods (Days) } & \multicolumn{5}{|c|}{ Storage Periods (Days) } \\
\hline & $\mathbf{0}$ & 5 & 10 & 15 & Mean & $\mathbf{0}$ & 5 & 10 & 15 & Mean \\
\hline Control & 0.242 & 0.210 & 0.182 & 0.160 & 0.198 & 0.257 & 0.225 & 0.205 & 0.187 & 0.218 \\
\hline NPPEP & 0.242 & 0.227 & 0.223 & 0.212 & 0.226 & 0.257 & 0.241 & 0.235 & 0.231 & 0.241 \\
\hline LPPEP & 0.242 & 0.225 & 0.218 & 0.210 & 0.223 & 0.257 & 0.239 & 0.234 & 0.229 & 0.239 \\
\hline MPPEP & 0.242 & 0.213 & 0.205 & 0.172 & 0.208 & 0.257 & 0.224 & 0.223 & 0.208 & 0.228 \\
\hline NPPPP & 0.242 & 0.240 & 0.237 & 0.227 & 0.236 & 0.257 & 0.250 & 0.246 & 0.240 & 0.248 \\
\hline LPPPP & 0.242 & 0.237 & 0.231 & 0.219 & 0.232 & 0.257 & 0.248 & 0.243 & 0.237 & 0.246 \\
\hline MPPPP & 0.242 & 0.223 & 0.214 & 0.207 & 0.221 & 0.257 & 0.232 & 0.228 & 0.220 & 0.234 \\
\hline \multirow[t]{2}{*}{ Mean } & 0.242 & 0.225 & 0.215 & 0.201 & & 0.257 & 0.236 & 0.230 & $0.221 \mathrm{c}$ & \\
\hline & $\mathrm{T}$ & & & & $=0.013$ & $\mathrm{~T}$ & & & & $=0.011$ \\
\hline \multirow[t]{2}{*}{ LSD at 0.05} & $\mathrm{D}$ & & & & $=0.010$ & $\mathrm{D}$ & & & & $=0.008$ \\
\hline & $\mathrm{T} \times \mathrm{D}$ & & & & $=\mathrm{NS}$ & $\mathrm{T} \times \mathrm{D}$ & & & & $=\mathrm{NS}$ \\
\hline
\end{tabular}

Abbreviations: LSD, least significant difference $(P<0.05), \mathrm{T}$, treatments, $\mathrm{D}$, storage time, $\mathrm{T} \times \mathrm{D}$, interaction, NS, non-significant.

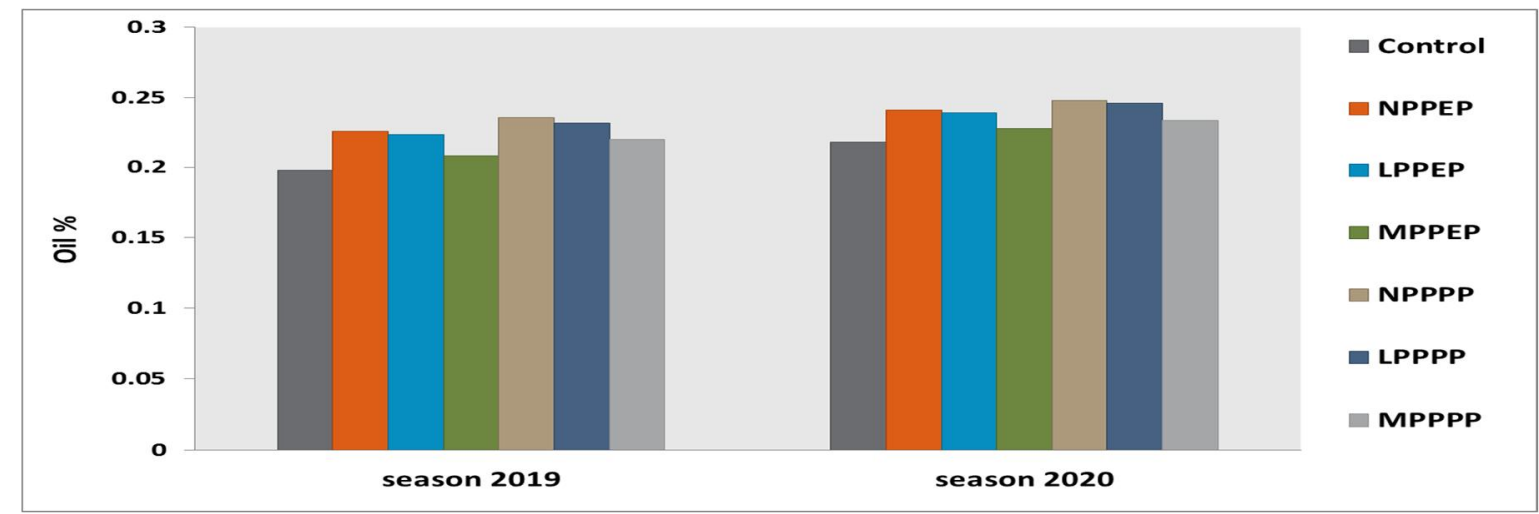

Fig. 8: Impact of packaging on volatile oil (\%) of fresh Ocimum basilicum, L. during 2019 and 2020 seasons.

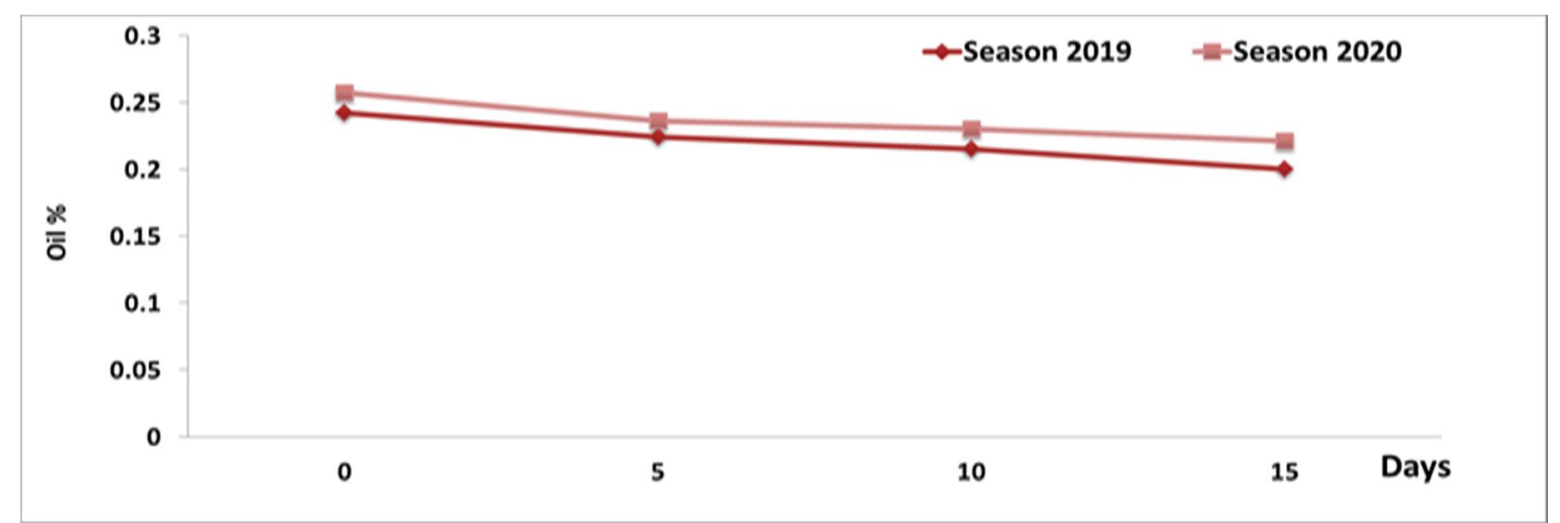

Fig. 9: Impact of period storage on volatile oil (\%) of fresh Ocimum basilicum, L. during 2019 and 2020 seasons. 


\subsection{Volatile oil constituents}

Effect of packing and cold storage on volatile oil constituents (\%) of fresh herb, The results of gas chromatography analysis (GC) indicated that the main components of EO were 1,8 cineole, linalool, borneol, terpineol, and eugenol (Table, 6).

Table 6: Effect of packing and cold storage on volatile oil constituents (\%) of fresh Basil (Ocimum basilicum, L.) during 2019 season.

\begin{tabular}{|c|c|c|c|}
\hline Compounds (\%) & Treatments & Starting point & Storage end \\
\hline \multirow{7}{*}{1,8 cineole } & Control & 11.56 & 11.82 \\
\hline & NPPEP & 11.56 & 12.55 \\
\hline & LPPEP & 11.56 & 12.21 \\
\hline & MPPEP & 11.56 & 12.94 \\
\hline & NPPPP & 11.56 & 11.75 \\
\hline & LPPPP & 11.56 & 12.01 \\
\hline & MPPPP & 11.56 & 12.58 \\
\hline \multirow{7}{*}{ Linalool, } & Control & 28.62 & 29.02 \\
\hline & NPPEP & 28.62 & 29.55 \\
\hline & LPPEP & 28.62 & 29.01 \\
\hline & MPPEP & 28.62 & 31.58 \\
\hline & NPPPP & 28.62 & 29.00 \\
\hline & LPPPP & 28.62 & 29.41 \\
\hline & МРPPP & 28.62 & 29.62 \\
\hline \multirow{7}{*}{ Borneol } & Control & 9.42 & 9.55 \\
\hline & NPPEP & 9.42 & 10.01 \\
\hline & LPPEP & 9.42 & 10.32 \\
\hline & MPPEP & 9.42 & 10.41 \\
\hline & NPPPP & 9.42 & 9.81 \\
\hline & LPPPP & 9.42 & 10.31 \\
\hline & MPPPP & 9.42 & 10.22 \\
\hline \multirow{7}{*}{ Terpineol } & Control & 6.21 & 6.45 \\
\hline & NPPEP & 6.21 & 5.50 \\
\hline & LPPEP & 6.21 & 6.02 \\
\hline & MPPEP & 6.21 & 6.52 \\
\hline & NPPPP & 6.21 & 5.51 \\
\hline & LPPPP & 6.21 & 6.31 \\
\hline & МРPPP & 6.21 & 4.99 \\
\hline \multirow{7}{*}{ Eugenol } & Control & 29.84 & 30.10 \\
\hline & NPPEP & 29.84 & 31.92 \\
\hline & LPPEP & 29.84 & 32.02 \\
\hline & MPPEP & 29.84 & 31.85 \\
\hline & NPPPP & 29.84 & 32.02 \\
\hline & LPPPP & 29.84 & 32.54 \\
\hline & MPPPP & 29.84 & 32.66 \\
\hline \multirow{7}{*}{ Other components } & Control & 14.35 & 13.06 \\
\hline & NPPEP & 14.35 & 10.47 \\
\hline & LPPEP & 14.35 & 10.42 \\
\hline & MPPEP & 14.35 & 6.70 \\
\hline & NPPPP & 14.35 & 11.91 \\
\hline & LPPPP & 14.35 & 9.42 \\
\hline & МРPPP & 14.35 & 9.93 \\
\hline
\end{tabular}

Our results were in harmony with the findings reported by Ismail (2006) found that Basil contain EO rich in active compounds, are linalool, cineole, eugenol, isocaryophyllene, methyl cinnamate and $\alpha$.-cubebene . Moreover, many authors reported that the main constituents are linalool, 1,8, cineol, eugenol, methyl cinnamate, camphor, methyl eugenol, methyl chavicol, $\beta$-elemene, $\beta$-ocimene, camphene, carvacrol, $\alpha$-bergamotene, $\alpha$-cadinol and geranial (Poonkodi, 2016). The defined components were linalool and eugenol as a main components followed by 1.8 cineole, borneol, camphor, $\alpha$-terpineol, methyl chavicole, terpinene-4-ol, terpinolene, $\beta$ - pinene, bornyl-acetate, $\alpha$ - 
pinene, camphene and $\beta$-caryophyllene while rest of the compounds were unknown (Shala, 2019). In this work, major compounds (\%) of EO in all PP and PE packages were an acceptable level during storage. Our findings were consistent with those reported by Silva et al., 2005 who recorded the two major components of the EO (basil) were eugenol and linalool, the eugenol and linalool relative content increased during storage, the eugenol content increased sharper than linalool content, and both components presented the highest content at the end of storage period.

\section{Conclusion}

Packaging materials i.e. polyethylene (PE), polypropylene (PP) as well as storage period and conditions have an effect on the quality from lost weight, decay, chlorophyll content, volatile oil and its main constituents. The PP packages (NPPPP - LPPPP - MPPPP) were better than PE packages (NPPEP - LPPEP - MPPEP) in keeping fresh basil during storage periods at an acceptable level, especially NPPPP, and LPPPP compared to other packages and control.

This study recommend that, we can use NPPPP, LPPPP from packaging materials to keep the quality and extend cold storage period of fresh Basil (Ocimum basilicum, L).

\section{References}

Abdel-Kader, H.H., EL-Hindi, Kh. H., Hekmat, Y. Massoud and Fatma, K. Badawy, 2009. Effect of cold storage and different packaging materials on the quality of fresh Rosemary herb: 1- Effects on marketing visual quality and shelf-life. J. Agric. Sci. Mansoura Univ., 34 (12): 11217 - 11231.

Avetisyan, A., A. Markosian, M. Petrosyan, N. Sahakyan, A. Babayan, S. Aloyan, and A. Trchounian, 2017. Chemical composition and some biological activities of the essential oils from basil Ocimum different cultivars. BMC Complementary and Alternative Medicine, 17(1): 1-8.

Barbosa, C.K.R., M.C.M. Fonseca, T.P. Silva, F.L. Finger, V.W.D. Casali, and P.R. Cecon, 2016. Effect of hydro cooling, packaging, and cold storage on the post-harvest quality of peppermint (Mentha piperita L.). Rev.bras. Plantas Med.,18(1):248-255.

BAS., 2019. Bulletin of the Agricultural Statistics, 2018/2019, part 1, 2.

Baytop T., 1984. Treatment with Plants in Turkey, Istanbul, Turkey, Istanbul Univ. Publ., No. 3255.

Bottcher, H., I. Gunther, and R. Franke, 2001. Comparative studies in the postharvest responses of different medicinal and culinary herbs. J. Article; Conference-Paper, 6(3): 129-137.

British Pharmacopoeia, 1963. Determination of Volatile Oil in Drugs. The Pharmaceutical Press, London.

Cantwell, M.I. and M.S. Reid, 1993. Postharvest physiology and handling of fresh culinary herbs. J. Herbs, Spices and Medicinal Plants, 1(3): 93-127.

Gang, D.R., J. Wang, N. Dudareva, K.H. Nam, J.E. Simon, E. Lewinsohn, and E. Pichersky, 2001. An investigation of the storage and biosynthesis of phenylpropenes in sweet basil. Plant physiology, 125 (2):539-555.

Gomez, E., J. Labarca, M. Guerrero, M. Marin, and B. Bracho, 1999. Postharvest performance of coriander (Coriandrum sativum L.) under refrigeration. Revista de Agronomia, Universidad delzulia 146-150. (Hort. Abst., 70 (4):3514).

Gomez, K.A. and A.A. Gomez, 1984. Statistical procedures for agricultural research. John Wiley \& Sons. $2^{\text {nd }} E d .: 8-22$.

Hossain, F., P. Follett, K.D. Vu, S. Salmieri, C. Senoussi, and M. Lacroix, 2014a. Radiosensitization of Aspergillus niger and Penicillium chrysogenum using basil essential oil and ionizing radiation for food. Food Control, 45: 156-162.

Hossain, F., M. Lacroix, S. Salmieri, K. Vu, and P.A. Follett, 2014b. Basil oil fumigation increases radiation sensitivity in adult Sitophilus oryzae (Coleoptera: Curculionidae). J. Stored Prod. Res. 59: 108-112.

Hoel, B.O. and K.A. Solhaug, 1998. Effect of irradiance on chlorophyll estimation with the Minolta SPAD-502 leaf chlorophyll meter. Ann. Bot. - London, 82: 389-392.

Hussain, A.I., F. Anwar, S.T.H. Sherazi, and R. Przybylski, 2008. Chemical composition, antioxidant and antimicrobial activities of basil (Ocimum basilicum) essential oils depends on seasonal variations. Food Chem., 108: 986-995. 
Ismail, M., 2006. Central properties and chemical composition of Ocimum basilicum essential oil. Pharm Biol; 44: 619-626.

Jirapong, C., N. Sriraveeroj, and C. Wongs-Aree, 2010. Abscission of sweet basil leaves induced by ethylene under modified atmosphere packaging. Acta Hortic., 875: 431-434 DOI: 10.17660/ActaHortic.875.56.

Karagözlü, N., B. Ergönül, and D. Özcan, 2011. Determination of antimicrobial effect of mint and basil essential oils on survival of $E$. coli $\mathrm{O} 157: \mathrm{H} 7$ and S. typhimuriumin fresh cut lettuce and purslane. Food Control, 22: 1851-1855.

Lange, D.L., 2000. New film technologies for horticultural products. Hort. Technology, 10: 486-490.

Loaiza, J. and M. Cantwell, 1997. Postharvest physiology and quality of cilantro (Coriandrum sativum L.). Hort. Science, 32: 104-107.

Morris, J.A., A. Khettry, and E.W. Seitz, 1979. Antimicrobial activity of aroma chemicals and essential oils. J. Am. Oil Chem. Soc., 56: 595-603.

Poonkodi, K., 2016. Chemical composition of essential oil of Ocimum basilicum L. (Basil) and its biological activities-an overview. J. Crit. Rev., 3 (3):56-62.

Popovic, Z., M. Kostic, S. Popovic, and S. Skoric, 2006. Bioactivities of essential oils from basil and sage to Sitophilus oryzae L. Biotechnol \& Biotechnol. Equip., 20: 36-40.

Rashed Nahed M. M. and S.I. Younis, 2010. Effect of Different Package Film on the Quality of Fresh Origanum Syriacum, L. Herb. J. of App. Sci. Res., 6(1): 6-12.

Rashed, Nahed M.M., 2007. Postharvest studies on the storability of rosemary and thyme plants .Ph.D. Thesis, Fac. Agric., Kafr El-Sheikh Univ., Egypt.

Rizzo, V. and G. Muratore, 2009. Effects of packaging on shelf life of fresh celery. J. Food Engineering, 90: 124-128.

Sharma, R., S. Bhatia and P. Kaur, 2018. Influence of packaging and storage conditions on biochemical quality and enzymatic activity in relation to shelf life enhancement of fresh basil leaf. J. Food Sci. Technol., 55(8):3199-3211.

Shala, A.Y., 2019. Effect of Different Doses of Gamma Irradiation on Vegetative Growth and Oil Yield of Ocimum basilicum L. J. Plant Production, Mansoura Univ.,10 (1): 1-6.

Silva, F., and V.W.D. Casali, 2000. Plantas medicinais e aromáticas: pós-colheita e óleos essenciais; pós-colheita e óleos essenciais. Universidade Federal de Viçosa, 135.

Silva, F., R.H.S. Santos, N.J. Andrade, L.C.A. Barbosa, V.W.D. Casali, R.R., Lima, and R.V.M. Passarinho, 2005. Basil conservation affected by cropping season, harvest time and storage period. Pesquisa Agropecuaria Brasileira, 40: 323-328.

Tay, F.R.X. and S.S. Teo, 2019. Interactive effects of storage temperatures and packaging methods on sweet basil. MOJ Food Process. \& Technol.,7(1):16-20. DOI: 10.15406/mojfpt.2019.07.00213.

Watkins, C.B. and J.F. Nock, 2012. Production Guide for Storage of Organic Fruits and Vegetables. NYS IPM Publ. 10: 39-40.

Wongsheree, T., S. Ketsa and W.G.V. Doorn, 2009. The relationship between chilling injury and membrane damage in lemon basil (Ocimum x Citriodorrum) leaves. Postharvest Biol. Technol., 51:91-96. 